\title{
Incorporation of vitamin $\mathbf{E}$ in poly(3hydroxybutyrate)/Bioglass composite films: effect on surface properties and cell attachment
}

\author{
Superb K. Misra ${ }^{1}$, Sheryl E. Philip ${ }^{2}$, Wojciech Chrzanowski ${ }^{3}$, \\ Showan N. Nazhat ${ }^{4}$, Ipsita Roy ${ }^{2}$, Jonathan C. Knowles ${ }^{3}$, Vehid Salih ${ }^{3}$ \\ and Aldo R. Boccaccini ${ }^{1, *}$ \\ ${ }^{1}$ Department of Materials, Imperial College London, London $S W^{r}$ 2AZ, UK \\ ${ }^{2}$ Department of Molecular and Applied Biosciences, University of Westminster, \\ London $W 1 W 6 U W, U K$ \\ ${ }^{3}$ Division of Biomaterials and Tissue Engineering, UCL Eastman Dental Institute, \\ London WC1X 8LD, UK \\ ${ }^{4}$ Department of Mining and Materials Engineering, McGill University, Montreal, Quebec, \\ Canada H3А 2B2
}

\begin{abstract}
This study investigated the possibility of incorporating $\alpha$-tocopherol (vitamin E) into poly (3hydroxybutyrate) $(\mathrm{P}(3 \mathrm{HB})) /$ Bioglass composites, which are being developed for bone tissue engineering matrices. $\mathrm{P}(3 \mathrm{HB})$ films with $20 \mathrm{wt} \%$ Bioglass and $10 \mathrm{wt} \%$ vitamin $\mathrm{E}$ were prepared using the solvent casting technique. Addition of vitamin $\mathrm{E}$ significantly improved the hydrophilicity of the composites along with increasing the total protein adsorption. The presence of protein adsorbed on the composite surface was further confirmed using X-ray photoelectron spectroscopy analysis. Preliminary cell culture studies using MG-63 human osteoblasts showed that the addition of vitamin $\mathrm{E}$ in the $\mathrm{P}(3 \mathrm{HB}) / 20 \mathrm{wt} \%$ Bioglass films significantly increased cell proliferation. The results achieved in this study confirmed the possibility of incorporating vitamin $\mathrm{E}$ as a suitable additive in $\mathrm{P}(3 \mathrm{HB}) /$ Bioglass composites to engineer the surface of the composites by promoting higher protein adsorption and increasing the hydrophilicity.
\end{abstract}

Keywords: poly(3hydroxybutyrate); Bioglass; $\alpha$-tocopherol; MG-63 osteoblasts; composites, tissue engineering

\section{INTRODUCTION}

Tissue engineering strategies using scaffolds as matrices for cell support, which effectively act as extracellular matrix (ECM), have become a promising approach towards hard tissue repair and regeneration (Baksh et al. 1998; Chaikof et al. 2002). Although, in general, polymeric scaffolds can be used on their own for tissue engineering (Seal et al. 2001), for bone tissue regeneration polymers lack the required properties, in particular mechanical strength and osteoconductivity. The use of bioactive ceramics and glasses (e.g. hydroxyapatite, calcium phosphates, Bioglass) in combination with biodegradable polymers has therefore been proposed to develop composite scaffolds with enhanced mechanical and structural properties (Hutmacher 2001;

*Author for correspondence (a.boccaccini@imperial.ac.uk).

Electronic supplementary material is available at http://dx.doi.org/ 10.1098/rsif.2008.0278 or via http://journals.royalsociety.org.
Rezwan et al. 2006). Various combinations of materials have been considered to prepare composite scaffolds, such as poly DL-lactic acid (PDLLA)/Bioglass, collagen/ hydroxyapatite, poly(hydroxybutyrate-co-hydroxyvalerate)/wollastonite, poly(lactic-co-glycolic acid)/ HA, polycaprolactone/calcium phosphate, and others as reviewed elsewhere (Rezwan et al. 2006; Yefang et al. 2007). In addition to providing a structural support while new tissue regenerates, scaffolds must also provide the biological signals and they are therefore usually loaded with growth factors, antibiotics and bone morphogenic proteins or they can even be used as delivery vehicles for the release of drugs/proteins or genes (Gittens \& Uludag 2001).

It has been found that, in cases of bone tissue applications, the presence of oxygen-derived free radicals can lead to a gradual decrease in bone formation (Garette et al. 1990). The decrease in the number and activity of osteoblasts, responsible for synthesizing new bone matrix, is an important factor 
in the development of osteoporosis. Such cases have usually been linked with the increased presence of oxygen radicals and decreased levels of antioxidants (Arjmandi et al. 2002). Accumulation of such free radicals is associated with the bone resorption activity of osteoclasts and has been shown to be toxic towards osteoblasts (Garette et al. 1990). It is thus of considerable interest to introduce antioxidants within biological systems through tissue engineering scaffolds as carriers for these compounds, as proposed in this study. The incorporation of such antioxidant factors will allow a suitable substrate to enhance the growth of osteoblasts and simultaneously diminish the activity of osteoclasts.

Vitamin E is a well-documented lipid-soluble antioxidant within biological systems that protects structures and functions of cell membranes from free radical damage (Lucy \& Dingle 1964; Brigelius et al. 2002). In vivo and in vitro results have shown that the presence of vitamin E can act as a free radical scavenger and suppress bone resorption while stimulating bone formation ( $\mathrm{Xu}$ et al. 1995). Moreover, vitamin $\mathrm{E}$ deficiency has been shown to cause a decrease in the mechanical strength of bone (Melhus et al. 1999; Arjmandi et al. 2002). Vitamin E, being a natural product, has tested positive for the biocompatibility of its degradation products and has hence been approved by the Food and Drug Administration to be used in food and contact applications. Apart from being a strong antioxidant, vitamin E also aids the optimal development and maintenance of the human nervous system and skeletal muscle, acts as an anti-inflammatory agent (Devraj et al. 1996) and is reported to help in preventing heart diseases (Pryor 2000). The use of vitamin $\mathrm{E}$ has been explored extensively in biomaterial science to increase the in vivo biostability of polymers (poly(etherurethane) and ultra high molecular weight polyethylene), by inhibiting oxidation and crosslinking of the polyether soft segments (Reno \& Cannas 2006). In addition, vitamin $\mathrm{E}$, when added to a biodegradable polymeric phase such as PDLLA, has been shown to produce a more hydrophilic surface (Reno et al. 2005).

The polymeric substrate chosen for this study is poly(3hydroxybutyrate) $(\mathrm{P}(3 \mathrm{HB}))$, which is a common polymer from the biodegradable polyhydroxyalkanoate family, and it has shown favourable responses for various biomedical applications (Chen \& Wu 2005; Valappil et al. 2006). Moreover, the combination of $\mathrm{P}(3 \mathrm{HB})$ with bioactive ceramics has been shown to exhibit favourable properties for hard-tissue engineering applications (Misra et al. 2006) (see the electronic supplementary material). Recently, a new member in the $\mathrm{P}(3 \mathrm{HB}) /$ bioceramic composite family, i.e. $\mathrm{P}(3 \mathrm{HB}) /$ Bioglass, has been reported to have highly bioactive and biocompatible properties as well as exhibiting mechanical competence (Misra et al. 2007, 2008). Owing to the proven positive effects of vitamin $\mathrm{E}$ in the treatment of bone-related diseases, this antioxidant was used in this study as an additive in the $\mathrm{P}(3 \mathrm{HB})$ / Bioglass composite system to investigate its effect on the surface properties as well as on growth and attachment of osteoblast cells. This study thus represents the
Table 1. Samples prepared in this study with the appropriate concentration of Bioglass and vitamin E (wt\%).

\begin{tabular}{lcc}
\hline samples & Bioglass & vitamin E \\
\hline sample 1 & 0 & 0 \\
sample 2 & 0 & 10 \\
sample 3 & 20 & 0 \\
sample 4 & 20 & 10 \\
\hline
\end{tabular}

preliminary step for assessing the viability of optimized biodegradable and bioactive scaffolds for bone tissue engineering with an added antioxidant compound.

\section{EXPERIMENTAL METHODS}

\subsection{Materials}

All chemicals for polymer production and composite preparation were obtained from Sigma-Aldrich Company Ltd (Poole, UK). P(3HB) was produced and extracted from the Bacillus spp. (Valappil et al. 2007). Vitamin E (D- $\alpha$-tocopherol), foetal bovine serum (FBS) and phosphate-buffered saline (PBS) were obtained from Sigma-Aldrich Company Ltd. A melt-derived bioactive glass powder (Bioglass grade 45S5) was used in this study with mean particle size less than $5 \mu \mathrm{m}$, and with a composition of the following: $45 \mathrm{wt} \% \quad \mathrm{SiO}_{2}$; 24.5 wt $\% \quad \mathrm{Na}_{2} \mathrm{O} ; 24.5 \mathrm{wt} \% \mathrm{CaO} ;$ and 6 wt $\% \quad \mathrm{P}_{2} \mathrm{O}_{5}$. Details about the properties of this bioactive glass and its applications in tissue engineering have been reported in the literature (Hench 1998).

\subsection{Polymer and composite film preparation}

Polymeric films containing Bioglass particles and vitamin $\mathrm{E}$ were prepared using the solvent casting approach. Chloroform was used to dissolve $\mathrm{P}(3 \mathrm{HB})$ using an initial polymer weight to solvent ratio of 3 per cent (wt/vol). Four different samples with a fixed concentration of Bioglass particles (20 wt $\%$ ) and vitamin $\mathrm{E}(10 \mathrm{wt} \%)$ were prepared, as described in table 1. Vitamin E was purchased and used in the liquid form. It was incorporated within the microstructure of the film at the point of film synthesis by mixing the vitamin E liquid solution with the polymer solution. The wt $\%$ of added vitamin $\mathrm{E}$ was calculated using the density of vitamin $\mathrm{E}(0.950 \mathrm{~g} / \mathrm{ml})$ and the measured volume of suspension. The composite samples incorporating vitamin $\mathrm{E}$ and Bioglass (particle size less than $5 \mu \mathrm{m}$ ) were prepared by adding them (in their respective concentrations as outlined in table 1) to the polymer solution and sonicating (Ultrasonic Homogenizers US200, Philip Harris Scientific, Leicestershire, UK) the suspension for 1-2 min to ensure a homogeneous distribution of vitamin $\mathrm{E}$ and Bioglass particles in the polymer solution. The films were then cast on glass Petri dishes and allowed to dry at room temperature in a dark room. The dried films were stored at $4^{\circ} \mathrm{C}$ for not more than 7 days, for further analysis. 


\subsection{Physical characterization}

2.3.1. Scanning electron microscopy (SEM). Microstructural observations of the samples were performed using a JEOL 5610LV instrument (JEOL, Peabody, MA, USA). The composite samples were gold coated using a gold sputtering device (EMITECH-K550), operating at a pressure of $7 \times 10^{-2}$ bar and deposition current of $20 \mathrm{~mA}$ for $2 \mathrm{~min}$. SEM images were taken at various magnifications.

2.3.2. Protein adsorption study. A protein adsorption assay was carried out on the samples using FBS (Sigma Aldrich). Analysis was performed in triplicate. The samples $\left(1 \mathrm{~cm}^{2}\right)$ were incubated with $200 \mu \mathrm{l}$ of undiluted FBS in $1.5 \mathrm{ml}$ Eppendorf tubes and incubated at $37^{\circ} \mathrm{C}$ for $24 \mathrm{~h}$. The serum was then removed and the samples washed thrice with PBS. The proteins adsorbed on the samples were further collected by incubating the samples with $1 \mathrm{ml}$ of 2 per cent sodium dodecyl sulphate (SDS) in $\mathrm{PBS}$ for $24 \mathrm{~h}$ at room temperature and under vigorous shaking. The amount of total protein adsorbed by the samples was measured by using a commercial protein quantification kit (Pierce, Rockford, IL, USA). The optical density of the samples was measured spectrophotometrically at $562 \mathrm{~nm}$ against a calibration curve using bovine serum albumin as per the manufacturer's protocol.

2.3.3. X-ray photoelectron spectroscopy. Chemical composition of the surface was measured using X-ray photoelectron spectroscopy (XPS) (Thermo Escalab 220iXL). Measurements were performed using an Al K $\alpha$ monochromated X-ray source and quantified using CASAXPS (Casa Software Ltd, Teignmouth, UK). In the evaluation, a Shirley background type was used. For all the samples, both survey and high-resolution spectra were recorded. In the first instance, samples that were not incubated in FBS were measured. In the next step, the same set of samples was incubated with FBS and the XPS measurements were performed to detect the differences in chemical composition with special attention to the nitrogen concentration. Owing to the charging character of the samples, silver mask and charge compensation were used.

2.3.4. Contact angle study. Contact angle measurements using sessile drop methods were carried out in order to evaluate the wettability of the composite samples. The experiment was carried out on a KSV Cam 200 optical contact angle meter (KSV Instruments Ltd, Helsinki, Finland). An equal volume of water (less than $14 \mu \mathrm{l}$ ) was placed on every sample by means of a gas-tight microsyringe forming a drop. Photographs (frame interval, $1 \mathrm{~s}$; number of frames, 100) were taken to record the shape of the drops. The water contact angles on the specimens were measured by analysing the recorded drop images (four or five repeats for each sample) using the CAm200 software (KSV).

\subsection{In vitro cell culture studies}

In vitro cell culture studies were performed on the samples using the MG-63 osteoblast-like, human osteosarcoma cell line. The cells were cultured in growth medium (Dulbecco's modified Eagle's medium (DMEM), PAA, Coelbe, Germany), supplemented with 10 per cent $(\mathrm{v} / \mathrm{v})$ foetal calf serum, 1 per cent $(\mathrm{v} / \mathrm{v})$ penicillin streptomycin solution and incubated at $37^{\circ} \mathrm{C}$ in a humidified atmosphere $\left(5 \% \mathrm{CO}_{2}\right.$ in $95 \%$ air $)$. The medium in the flasks was changed every 2 days. The samples $\left(1 \mathrm{~cm}^{2}\right)$ were UV sterilized for $30 \mathrm{~min}$ and passivated in DMEM culture medium for $12 \mathrm{~h}$, prior to

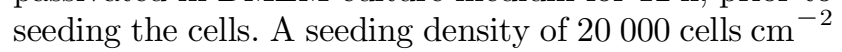
was used and cells were seeded using $1 \mathrm{ml}$ (20 000 cells) of DMEM medium. The plates were incubated in a humidified environment for a period of up to 7 days and the medium changed every second day. At specific time intervals, samples were analysed for cell proliferation and SEM observation. Analyses were carried out in triplicate and standard tissue culture plastic was used as the control.

2.4.1. Cell proliferation study. The cell proliferation study was carried out using the AlamarBlue assay (Abou Neel et al. 2007). AlamarBlue is an indicator dye that incorporates an oxidation-reduction indicator that both fluoresces and changes colour in response to the chemical reduction of growth medium, resulting from cell growth. The AlamarBlue assay kit offers a simple, rapid, reliable, sensitive, safe and cost-effective measurement of cell viability of the same population of cells maintained over a period of time in culture, which other conventional DNA (proliferation) tests do not accomplish. AlamarBlue is a metabolic assay, which is intimately linked and directly proportional to the number of cells present at a given time point. Thus, the fluorescent and colorimetric signals generated from the assay are proportional to the number of living cells in the sample. AlamarBlue (AbD Serotec, Kidlington, $\mathrm{UK})$ was added to the samples $(10 \% \mathrm{v} / \mathrm{v}$ of medium) and incubated at $37^{\circ} \mathrm{C}$ (with $5 \% \mathrm{CO}_{2}$ ) for $4 \mathrm{~h}$. Aliquots of $200 \mu \mathrm{l}$ from each sample well were transferred to a black 96-well plate and the fluorescence of the samples was measured using a fluorescence plate reader (Fluoroskan, Lab Systems) at $560\left(A_{560}\right)$ and 590 $\left(A_{590}\right) \mathrm{nm}$.

2.4.2. SEM preparation for cells. Films were examined under SEM after days 4 and 7 to assess the cell spreading and attachment on the surface of the samples. Details of sample preparation are mentioned elsewhere (Misra et al. 2008). Briefly, specimens were fixed overnight in 3 per cent glutaraldehyde in cacodylate buffer, followed by dehydration in graded alcohols, and were critical point dried using hexamethyldisilazane for $1 \mathrm{~min}$. Dried samples were gold coated and examined under SEM ( JEOL 5610LV).

\subsection{Statistical analysis}

All data are expressed as mean \pm s.d. The data were compared using Student's $t$-test and differences were considered significant when ${ }^{*} p<0.05$, very significant when ${ }^{* *} p<0.01$ and highly significant when ${ }^{* * *} p<0.001$. A $p$-value higher than $0.05(p>0.05)$ was taken as indicating no significant difference. 

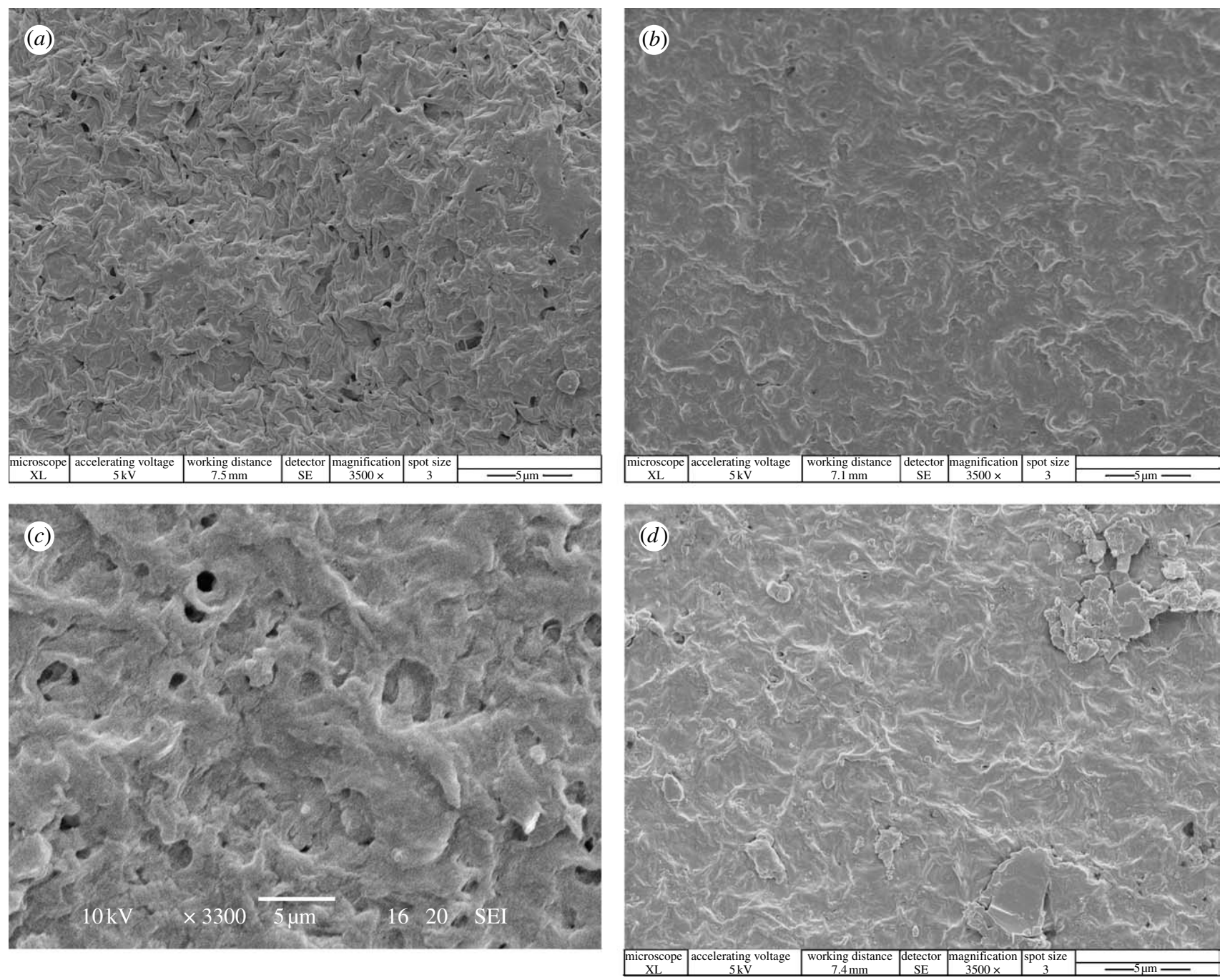

Figure 1. Scanning electron micrographs of the film's surface for $(a) \mathrm{P}(3 \mathrm{HB}),(b) \mathrm{P}(3 \mathrm{HB}) / 10 \mathrm{wt} \%$ vitamin $\mathrm{E},(c) \mathrm{P}(3 \mathrm{HB}) / 20 \mathrm{wt} \%$ Bioglass and $(d) \mathrm{P}(3 \mathrm{HB}) / 20 \mathrm{wt} \%$ Bioglass $/ 10 \mathrm{wt} \%$ vitamin $\mathrm{E}$.

\section{RESULTS AND DISCUSSION}

\subsection{Microstructural analysis}

It has been shown that adding an optimal quantity of vitamin $\mathrm{E}(10 \mathrm{wt} \%)$ to a polymeric matrix (e.g. PDLLA) does have a significant impact on the hydrophilicity and protein adsorption of the samples, when compared with a low quantity (1-5 wt\%) of vitamin $\mathrm{E}$ addition (Reno et al. 2005). Hence, for this investigation, only one fixed concentration of vitamin $\mathrm{E}$ (i.e. $10 \mathrm{wt} \%$ ) was added to test the efficacy of vitamin $\mathrm{E}$ addition on surface properties and biocompatibility of the $\mathrm{P}(3 \mathrm{HB}) /$ Bioglass composite system. The addition of vitamin $\mathrm{E}$ had no visible impact on the microstructure of the films when examined under SEM, as shown in figure 1 . No measurement was carried out to monitor the possible release of vitamin $\mathrm{E}$ in this study. However, it is suggested that vitamin $\mathrm{E}$ is bound to the composite structure throughout the matrix owing to the good dispersion achieved in the polymer solution stage. The effect of adding vitamin $\mathrm{E}$ was highlighted through the wettability and protein adsorption experiments performed on the samples. Addition of vitamin E showed a significant increase in the wettability of the composites by lowering the water contact angle

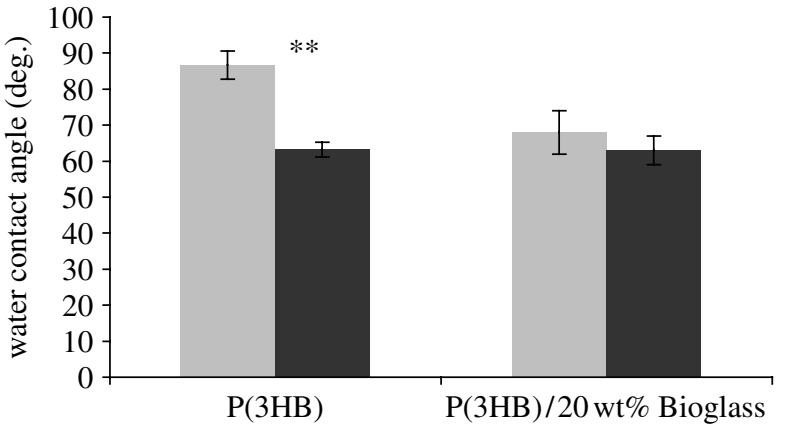

Figure 2. Comparison of the water contact angle measurements for vitamin E-loaded and -unloaded $\mathrm{P}(3 \mathrm{HB}) /$ Bioglass composites. The data $(n=4$; error bars $= \pm$ s.d. $)$ were compared using Student's $t$-test and differences were considered significant when ${ }^{* *} p<0.01$. Grey bars, no vitamin $\mathrm{E}$; black bars, $10 \mathrm{wt} \%$ vitamin $\mathrm{E}$.

(figure 2). The water contact angle of the $\mathrm{P}(3 \mathrm{HB})$ film reduced from $86 \pm 4^{\circ}$ to $63 \pm 2^{\circ}$ (decrease of $27 \%$; $n=5$, $\left.{ }^{* *} p<0.01\right)$ as a result of adding $10 \mathrm{wt} \%$ vitamin $\mathrm{E}$ to the polymer matrix. A similar trend was recorded for the $\mathrm{P}(3 \mathrm{HB}) / 20 \mathrm{wt} \%$ Bioglass films, wherein the contact angle decreased from $68 \pm 6^{\circ}$ to $63 \pm 3^{\circ}(n=4, p>0.05)$. It can thus be concluded that the vitamin E-enriched 
$\mathrm{P}(3 \mathrm{HB})$ and $\mathrm{P}(3 \mathrm{HB}) / 20 \mathrm{wt} \%$ Bioglass composite films were more easily wetted than the non-enriched films of the same kind. However, the extent of decrease in the hydrophobicity due to the addition of vitamin $\mathrm{E}$ was more evident for samples without Bioglass particles. The decrease in the hydrophobicity of the polymer in turn significantly affected protein adsorption and cell proliferation behaviour as will be discussed in the subsequent sections.

\subsection{Protein adsorption studies}

Protein adsorption studies using the commercial kit showed that the total amount of protein adsorbed on the surface was statistically higher for the samples containing vitamin $\mathrm{E}$ than for the non-vitamin E-enriched surfaces, as evident from the results shown in figure 3 . For example, the amount of total protein adsorbed on the $\mathrm{P}(3 \mathrm{HB})$ and $\mathrm{P}(3 \mathrm{HB}) / 20 \mathrm{wt} \%$ Bioglass samples was $171 \pm 20$ and $182 \pm 20 \mu \mathrm{g} \mathrm{cm}^{-2}$, respectively. Whereas, on addition of $10 \mathrm{wt} \%$ vitamin $\mathrm{E}$, the total protein adsorption on the surface increased to $693 \pm 50 \mu \mathrm{g} \mathrm{cm}{ }^{-2}$ (increase of $300 \% ; n=3,{ }^{* * *} p<0.001$ ) and $485 \pm$ $70 \mu \mathrm{g} \mathrm{cm}^{-2}$ (increase of $165 \% ; n=3,{ }^{* * *} p<0.001$ ) for $\mathrm{P}(3 \mathrm{HB})$ and $\mathrm{P}(3 \mathrm{HB}) / 20 \mathrm{wt} \%$ Bioglass, respectively. The SDS-PAGE profile for adsorbed proteins showed the presence of a main band at approximately $80 \mathrm{kDa}$, representing serum albumin (data not shown). A similar experiment conducted on PDLLA/vitamin E films by Reno et al. (2005) demonstrated the adsorbed protein to be albumin, which is also the most abundant plasma protein known to be responsible for the transport of a wide variety of metabolites, drugs, anionic ligands and cations. The increase in the protein adsorption may result from the nano/microstructural changes in the surface morphology as well as an increase in the hydrophilicity of the surface (Misra et al. 2008). There is increasing understanding of cell-material interface relationships, particularly related to protein adsorption. Culture media contain a large variety of different components, many of which are proteins intimately associated with cell attachment, spreading and proliferation. Moreover, the selective adsorption of specific protein components will determine the desired cell functions on biomaterials. Protein adsorption is of importance in the evaluation of the potential of a biomaterial for use as a tissue engineering scaffold, as most mammalian cells are anchorage dependent and need a biocompatible, protein-rich surface for attachment, differentiation and migration to form new tissue (Webster et al. 1999). It has been shown that cell adhesion takes place in two different stages. The first stage consists of the adsorption of water and a layer of proteins that selectively adhere to the biomaterial surface, mediated by the surface properties of the substrate (Navarro et al. 2006). The second stage involves cell adhesion onto the layer of proteins, which is a more complex process mediated by ECM, cell membrane and cytoskeletal proteins (Luthen et al. 2005). In our case, a combination of microstructural changes induced by the addition of Bioglass particles (figure 1) and the wettability change (figure 2) due to the incorporation of vitamin $\mathrm{E}$ seem to be the main cause

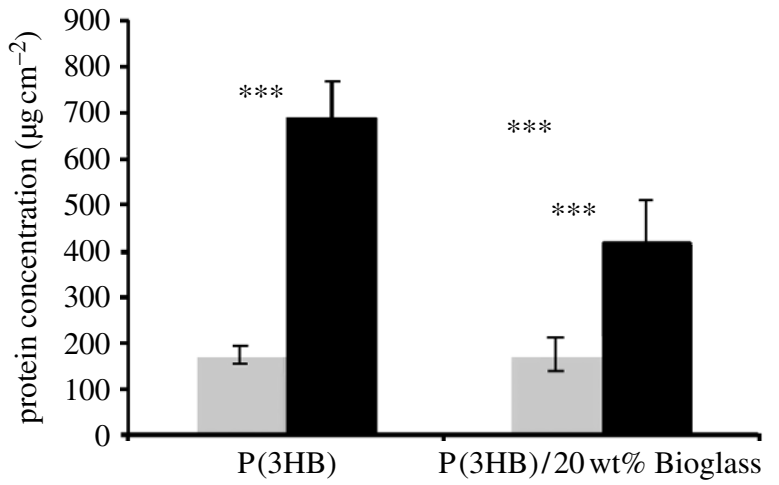

Figure 3. Total protein adsorption on the surface of the films, highlighting the significant differences induced by the addition of vitamin $\mathrm{E}$ on both $\mathrm{P}(3 \mathrm{HB})$ and composite $(\mathrm{P}(3 \mathrm{HB}) / 20 \mathrm{wt} \%$ Bioglass $)$ films. The data $(n=4$; error bars $= \pm$ s.d.) were compared using Student's $t$-test and the differences were considered significant when ${ }^{*} p<0.05$, ${ }^{* *} p<0.01$ and ${ }^{* * *} p<0.001$. Grey bars, no vitamin E; black bars, $10 \mathrm{wt} \%$ vitamin E.

leading to the increase in protein adsorption. This result is in agreement with the observation made by Collier et al. (1997) that albumin adsorbs preferably to hydrophilic surfaces, which seems to correlate with the wettability results of our samples (figure 2). A direct effect of the presence of vitamin $\mathrm{E}$ on the total albumin adsorption cannot be excluded, as it has been shown previously that afamin (one of the four constituents of the albumin gene family) is a specific binding protein to vitamin E (Voegele et al. 2002; Jerkovic et al. 2005). As a follow-up study, it is of vital importance to characterize the surface energy of the composites and to identify whether or not there is an affinity of certain specific proteins to bind with the composite's surface. This will further allow the use of the composites as a delivery vehicle for certain proteins to trigger specific cell responses when used as a tissue engineering scaffold.

\subsection{XPS evaluation of protein adsorption}

Assessment of the protein adsorption was done on the basis of nitrogen content in the samples before and after incubation with FBS. The presence of nitrogen can be related to protein, and thus allows for an indirect evaluation of protein adsorption onto the top surface layer. The chemical compositions of all tested samples are shown in table 2. For two of the sample types, $\mathrm{P}(3 \mathrm{HB})$ and $\mathrm{P}(3 \mathrm{HB}) / 10 \mathrm{wt} \%$ vitamin $\mathrm{E}$, a trace of nitrogen was observed before incubation with FBS. The binding energy of nitrogen $-\mathrm{N} 1 \mathrm{~s}\left(E_{\mathrm{b}}=399.5 \mathrm{eV}\right)-$ corresponded to single bonded nitrogen to carbon. This form is commonly seen on the sample surface and is associated with contamination.

A significant increase in nitrogen content was observed for all the samples post incubation with FBS. The greatest amount of nitrogen, i.e. $10 \mathrm{wt} \%$ was observed for vitamin E-containing $\mathrm{P}(3 \mathrm{HB}) /$ Bioglass composites (figure 4). For the same type of sample without vitamin $\mathrm{E}$, the nitrogen concentration was approximately $6 \mathrm{wt} \%$. However, no significant differences were observed for the samples without Bioglass additives and the concentration was 8 and 
Table 2. Chemical composition (at\%) of surfaces before and after incubation with FBS as determined by XPS analysis.

\begin{tabular}{|c|c|c|c|c|c|c|}
\hline sample nos. & $\mathrm{C}$ & $\mathrm{Ca}$ & $\mathrm{Cl}$ & $\mathrm{N}$ & $\mathrm{Na}$ & $\mathrm{Si}$ \\
\hline \multicolumn{7}{|c|}{ before incubation with FBS } \\
\hline sample 1 & $69.6 \pm 0.1$ & $0.4 \pm 0.1$ & $0.2 \pm 0.2$ & $0.5 \pm 0.1$ & $3.5 \pm 0.1$ & $1.2 \pm 0.1$ \\
\hline sample 2 & $68.9 \pm 5.1$ & - & $0.5 \pm 0.1$ & $0.4 \pm 0.3$ & $0.6 \pm 0.1$ & $2.6 \pm 0.1$ \\
\hline sample 3 & $68.5 \pm 0.8$ & $0.3 \pm 0.2$ & -1 & - & $4.5 \pm 0.2$ & $1.1 \pm 0.2$ \\
\hline sample 4 & $68.6 \pm 6.4$ & - & $0.5 \pm 0.1$ & - & $0.8 \pm 0.1$ & $2.3 \pm 0.5$ \\
\hline \multicolumn{7}{|c|}{ after incubation with FBS and washing with $P B S$} \\
\hline sample 1 & $59.2 \pm 0.3$ & $0.3 \pm 0.1$ & $1.1 \pm 0.1$ & $8.1 \pm 0.6$ & $3.1 \pm 0.5$ & $3.5 \pm 0.1$ \\
\hline sample 2 & $64.5 \pm 0.4$ & - & $2.9 \pm 0.03$ & $7.2 \pm 0.1$ & $3 \pm 0.4$ & $2.0 \pm 0.1$ \\
\hline sample 3 & $65.3 \pm 0.3$ & - & $2.2 \pm 0.2$ & $6.1 \pm 0.1$ & $3.3 \pm 0.4$ & $1.5 \pm 0.2$ \\
\hline sample 4 & $60.6 \pm 0.7$ & - & $1.3 \pm 0.04$ & $10 \pm 0.1$ & $2.7 \pm 0.5$ & $0.8 \pm 0.3$ \\
\hline
\end{tabular}

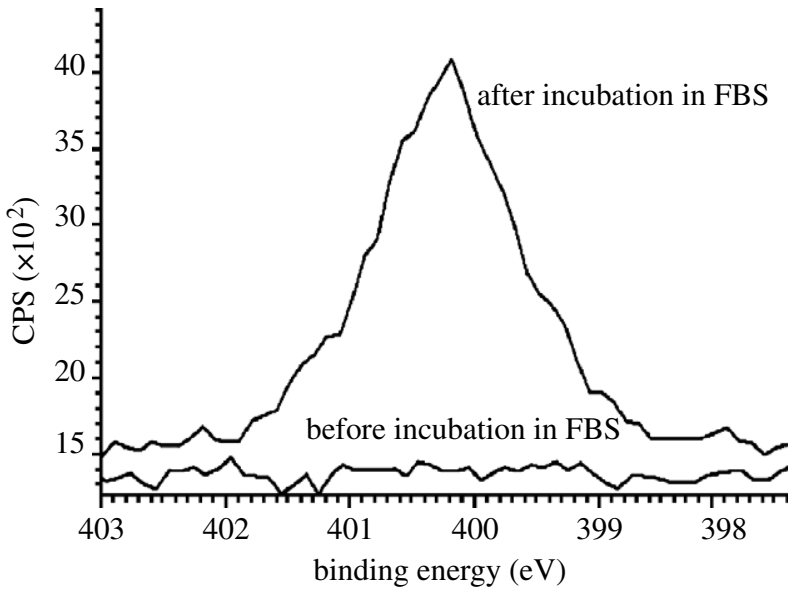

Figure 4. Nitrogen (N1s) high-resolution spectra of vitamin E-containing $\mathrm{P}(3 \mathrm{HB}) /$ Bioglass composites before and after protein adsorption.

7 wt\% for $\mathrm{P}(3 \mathrm{HB})$ and $\mathrm{P}(3 \mathrm{HB}) / 10 \mathrm{wt} \%$ vitamin $\mathrm{E}$, respectively. The binding energy for all the samples after incubation was very similar, $E_{\mathrm{b}}=400.2 \mathrm{eV}$, and corresponded to $\mathrm{N}-\mathrm{H}, \mathrm{N}-\mathrm{O}$ and $\mathrm{C}-\mathrm{N}$. The XPS results are partly in agreement with the protein adsorption study. It can be deduced from the XPS analysis that the vitamin E-enriched $\mathrm{P}(3 \mathrm{HB}) /$ Bioglass composites adsorbed a greater amount of protein than all the other samples. However, XPS measurement (without sputtering) is a surface analysis technique with a depth of a few nanometres and hence does not give the total protein adsorbed by the surface. In addition, for all samples incubated with FBS, an increase in chlorine was observed, which resulted from the washing step performed with PBS. The binding energy $\left(E_{\mathrm{b}}=199.9 \mathrm{eV}\right)$ of chloride is associated with poly(vinyl chloride). No additional changes in chemical composition were observed for both groups of samples.

\subsection{Cell culture studies}

Cell proliferation studies using MG-63 human osteosarcoma cells established the biocompatibility of the $\mathrm{P}(3 \mathrm{HB}) /$ Bioglass/vitamin E substrates (figure 5). The trend of the MG-63 cell proliferation over the 7-day period of study is shown in figure $5 a$. The growth of MG-63 cells on all substrates increased over the observed duration. In figure $5 b$, a relative cell proliferation
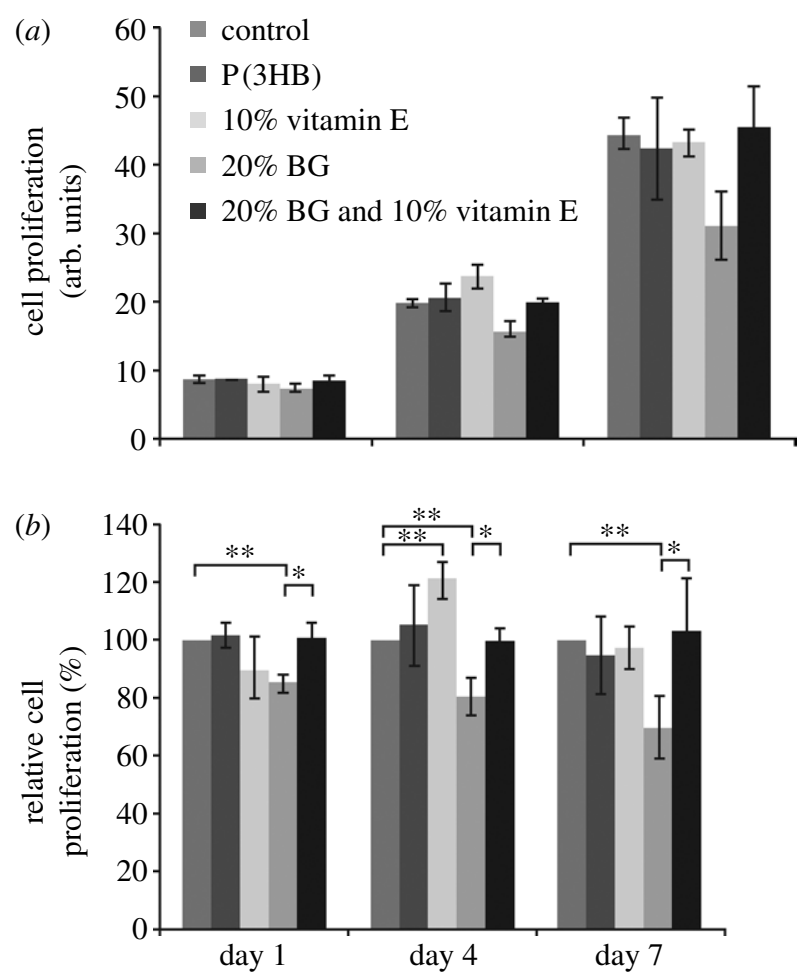

Figure 5. Cell proliferation study for 1, 4 and 7 days, using AlamarBlue assay on $(a)$ samples with and without vitamin E, (b) all tested samples relative to the control (control set to $100 \%)$. The data $(n=3$; error bars $= \pm$ s.d.) were compared using Student's $t$-test and differences were considered significant when ${ }^{*} p<0.05,{ }^{* *} p<0.01$. BG, Bioglass.

(comparison made with the control surface that was normalized to $100 \%$ ) of all samples is shown. The cell proliferation results indicate the following main features. (i) There is no significant difference between the control and $\mathrm{P}(3 \mathrm{HB})$ surfaces, thus suggesting the suitability of the polymer for hard tissue applications. (ii) Addition of $20 \mathrm{wt} \%$ Bioglass significantly $(n=3$, $\left.{ }^{* *} p<0.01\right)$ reduces the cell proliferation when compared with the control surface. This behaviour could be attributed to the high alkalinity in the surrounding medium induced by the initial dissolution products of the Bioglass particles. (iii) Incorporation of vitamin $\mathrm{E}$ in the polymeric matrix does not have a significant effect on cell proliferation, except for day 4 where $\mathrm{P}(3 \mathrm{HB}) / 10 \mathrm{wt} \%$ vitamin $\mathrm{E}$ samples induced a higher cell growth than the control surface $\left(n=3,{ }^{* *} p<0.01\right)$. 

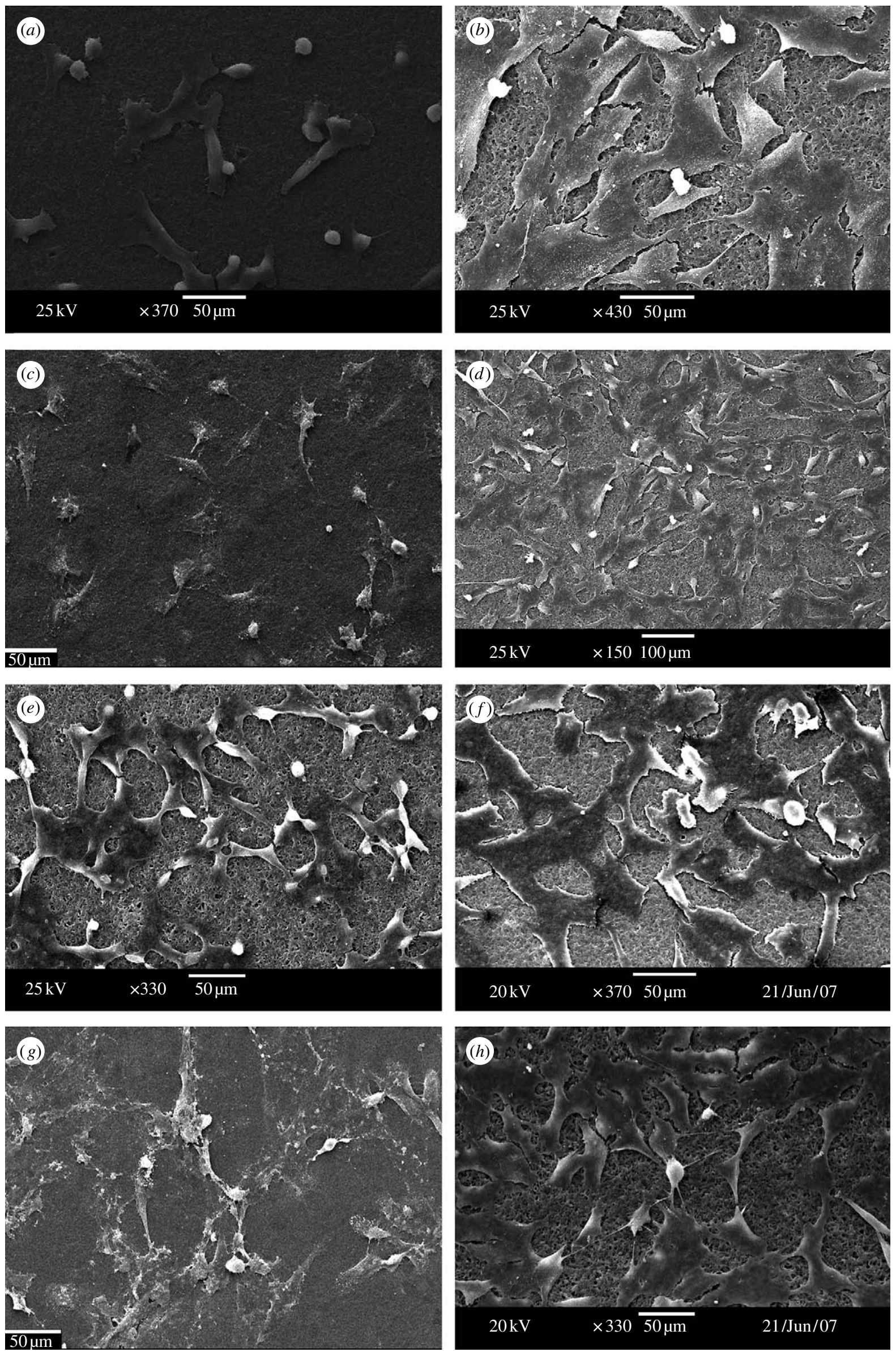

Figure 6. SEM micrographs highlighting the spreading, attachment and division of MG-63 cells when grown on $(a)$ sample 1 at day $4,(b)$ sample 1 at day $7,(c)$ sample 2 at day $4,(d)$ sample 2 at day $7,(e)$ sample 3 at day $4,(f)$ sample 3 at day $7,(g)$ sample 4 at day 4 and $(h)$ sample 4 at day 7. ( $a, b, e, f)$ Reproduced from Misra et al. (2008), with permission from Elsevier Publishing Ltd. 
(iv) The presence of vitamin $\mathrm{E}$ in $\mathrm{P}(3 \mathrm{HB}) / 20 \mathrm{wt} \%$ Bioglass had a positive effect on cell proliferation when compared with the $\mathrm{P}(3 \mathrm{HB}) / 20 \mathrm{wt} \%$ Bioglass composite system $\left(n=3,{ }^{*} p<0.05\right)$, for the entire observed period. While AlamarBlue is a well-established method for estimating cell proliferation in two-dimensional cultures, it is more frequently used to estimate the effectiveness in three-dimensional culture systems. It has been highlighted that such assays do not necessarily reflect the linear correlation with increasing cell densities in such in vitro systems and must be considered as estimates/approximations for quantifying cell numbers in vitro ( $\mathrm{Ng}$ et al. 2005). The quantitative cell proliferation results were further validated by microscopic examination of the samples for possible cell attachment. A possible explanation for the increase in cell proliferation in sample 4 compared with sample 3 is the increased protein adsorption induced by the presence of vitamin $\mathrm{E}$ (figure 3 ) and the possible effect of $\mathrm{pH}$ on the presence of vitamin $\mathrm{E}$ on the surface of the Bioglass particles/composite. This aspect remains however to be quantitatively confirmed. The quantitative cell proliferation results were further validated by microscopic examination of the samples for possible cell attachment. In figure 6, SEM micrographs of MG-63 cells grown on all the substrates investigated after days 4 and 7 are shown. The differences in cell morphology, shape and degree of attachment to the substrates are distinct for all the samples between days 4 and 7 . The cell density on all substrates at day 4 is lower than that at day 7 and also the cells have a more outspread morphology at day 7 . The attachment of cells on composite samples and the intracellular communication of cells with one another were evident on all examined samples. There were no significant qualitative differences observed in cell attachment between the vitamin E-loaded and -unloaded samples. The cell proliferation results obtained thus suggest that the significant increase in protein adsorption due to the incorporation of vitamin $\mathrm{E}$ translates to the cytocompatibility/proliferation of the MG-63 cells. This is an expected observation, as protein adsorption is of importance in the evaluation of the potential of a biomaterial for use as a tissue engineering scaffold since most mammalian cells are anchorage dependent and need a biocompatible, protein-rich surface for attachment, differentiation and migration to form new tissue (Webster et al. 1999), as discussed in $\$ 3.2$. It can thus be concluded that the addition of vitamin E rendered an improved biocompatible surface for cell attachment and proliferation, with significant improvement for $\mathrm{P}(3 \mathrm{HB}) /$ Bioglass composite samples compared with $\mathrm{P}(3 \mathrm{HB})$ samples.

\section{CONCLUSIONS}

Successful results obtained by using vitamin E in orthopaedic applications have prompted the present experimental study. We have looked for the first time at the efficacy of using vitamin $\mathrm{E}$ in a $\mathrm{P}(3 \mathrm{HB}) /$ Bioglass composite system, aimed towards developing scaffolds (electronic supplementary material) for bone tissue engineering applications. The results from the static contact angle measurements suggested that the incorporation of vitamin $\mathrm{E}$ improves the wettability of the samples and thus vitamin E-containing composites are more hydrophilic. This increase in wettability was further complemented by the total protein adsorption study on the materials. Inclusion of vitamin $\mathrm{E}$ in both the $\mathrm{P}(3 \mathrm{HB})$ and $\mathrm{P}(3 \mathrm{HB}) / 20 \mathrm{wt} \%$ Bioglass samples significantly increased the total protein adsorption as shown in the protein adsorption and XPS study. A future investigation should establish the quantitative correlation between the water contact angle measured on these materials and the quantity of protein adsorbed in the presence or absence of vitamin E. Albumin was reported to be the major protein adsorbed; the ability of the sample to adsorb proteins in a selective manner is presently being investigated. The conducive MG-63 cell proliferation results on composite samples further reinforces the proposed approach of using vitamin $\mathrm{E}$ in tissue engineering scaffolds for bone regeneration.

The authors gratefully acknowledge the financial help of an Overseas Research Scholarship. Assistance from Dr Graham Palmer (Eastman Dental Institute, UCL) and Frank Courtes (Institut National Des Sciences Appliquees, France) for contact angle measurement and polymer production is also acknowledged. We also thank Mr Johann Cho (Imperial College) for his assistance with SEM analysis.

\section{REFERENCES}

Abou Neel, E. A., Mizoguchi, T., Ito, M., Bitar, M., Salih, V. \& Knowles, J. C. 2007 In vitro bioactivity and gene expression by cells cultured on titanium dioxide doped phosphate-based glasses. Biomaterials 28, 2967-2977. (doi:10.1016/j.biomaterials.2007.03.018)

Arjmandi, B. H., Juma, S., Beharka, A., Bapna, M. S., Akhter, M. \& Meydani, S. N. 2002 Vitamin E improves bone quality in the aged but not in young adult male mice. J. Nutr. Biochem. 13, 543-549. (doi:10.1016/S09552863(02)00199-7)

Baksh, D., Davies, J. E. \& Kim, S. 1998 Three-dimensional matrices of calcium polyphosphates support bone growth in vitro and in vivo. J. Mater. Sci. Mater. Med. 9, 743-748. (doi:10.1023/A:1008959103864)

Brigelius, F. R., Kelly, F. J., Salonen, J. T., Neuzil, J., Zingg, J. M. \& Azzi, A. 2002 The European perspective on vitamin E: current knowledge and future research. $\mathrm{Am}$. J. Clin. Nutr. 76, 703-716.

Chaikof, E. L., Matthew, H., Kohn, J., Mikos, A. G., Prestwich, G. D. \& Yip, C. M. 2002 Biomaterials and scaffolds in reparative medicine. Ann. N. Y. Acad. Sci. 961, 96-105.

Chen, G. Q. \& Wu, Q. 2005 The application of polyhydroxyalkanoate as tissue engineering materials. Biomaterials 26, 6565-6578. (doi:10.1016/j.biomaterials.2005.04.036)

Collier, T. O., Jenney, C. R., Defife, K. M. \& Anderson, J. M. 1997 Protein adsorption on chemically modified surfaces. Biomed. Sci. Instrum. 33, 178-183.

Devraj, S., Li, D. \& Jialal, I. 1996 The effects of alpha tocopherol supplementation on monocyte function. Decreased lipid oxidation, interleukin 1 beta secretion and monocyte adhesion to endothelium. J. Clin. Invest. 98, 756-763. (doi:10.1172/JCI118848)

Garette, I. R., Boyce, B. F., Oreffo, R. O., Bonewald, L., Poser, J. \& Mundy, G. R. 1990 Oxygen-free radicals 
stimulate osteoclastic bone resorption in rodent bone in vitro and in vivo. J. Clin. Invest. 85, 632-639. (doi:10. 1172/JCI114485)

Gittens, S. A. \& Uludag, H. 2001 Growth factor delivery for bone tissue engineering. J. Drug Target. 9, 407-429.

Hench, L. L. 1998 Biomaterials: a forecast for the future. Biomaterials 19, 1419-1423. (doi:10.1016/S0142-9612(98) 00133-1)

Hutmacher, D. W. 2001 Scaffolds in tissue engineering bone and cartilage. Biomaterials 21, 2529-2543. (doi:10.1016/ S0142-9612(00)00121-6)

Jerkovic, L. et al. 2005 Afamin is a novel human vitamin $\mathrm{E}$ binding glycoprotein characterization and in vitro expression. J. Proteome Res. 4, 889-899. (doi:10.1021/ pr0500105)

Lucy, J. A. \& Dingle, J. T. 1964 Fat soluble vitamins in biological membranes. Nature 204, 156-160. (doi:10.1038/ 204156a0)

Luthen, F., Lange, R., Becker, P., Rychly, J., Beck, U. \& Barbara Nebe, J. G. 2005 The influence of surface roughness of titanium on $\beta 1$-and $\beta 3$-integring adhesion and the organisation of fibronectin in human osteoblastic cells. Biomaterials 26, 2423-2440. (doi:10.1016/j.biomaterials.2004.07.054)

Melhus, H., Michaelsson, K., Holmberg, L., Wolk, A. \& Ljunghall, S. 1999 Smoking, antioxidant vitamins, and the risk of hip fracture. J. Bone Miner. Res. 14, 129-135. (doi:10.1359/jbmr.1999.14.1.129)

Misra, S. K., Valappil, S. P., Roy, I. \& Boccaccini, A. R. 2006 Polyhydroxyalkanoate (PHA)/inorganic phase composites for tissue engineering applications. Biomacromolecules 7, 2249-2258. (doi:10.1021/bm060317c)

Misra, S. K., Nazhat, S. N., Valappil, S. P., Torbati, M. M., Wood, R. J. K., Roy, I. \& Boccaccini, A. R. 2007 Fabrication and characterization of biodegradable poly(3-hydroxybutyrate) composite containing Bioglass. Biomacromolecules 8, 2112-2119. (doi:10.1021/bm07 01954)

Misra, S. K., Mohn, D., Brunner, T. J., Stark, W. J., Philip, S. E., Roy, I., Salih, V., Knowles, J. C. \& Boccaccini, A. R. 2008 Comparison of nanoscale and microscale bioactive glass on the properties of $\mathrm{P}(3 \mathrm{HB}) /$ Bioglass composites. Biomaterials 29, 1750-1761. (doi:10.1016/j.biomaterials. 2007.12.040)

Navarro, M., Aparicio, C., Harris, C. M., Ginebra, P., Engel, E. \& Planell, J. A. 2006 Development of biodegradable composite scaffold for bone tissue engineering: physiochemical, topographical, mechanical, degradation and biological properties. Adv. Polym. Sci. 200, 209-231. (doi:10.1007/12_068)
Ng, K. W., Leong, D. T. W. \& Hutmacher, D. W. 2005 The challenge to measure cell proliferation in two and three dimensions. Tissue Eng. 11, 182-191. (doi:10.1089/ten. 2005.11.182)

Pryor, W. A. 2000 Vitamin E and heart diesease: basic science to clinical intervention trials. Free Radic. Biol. Med. 28, 141-164. (doi:10.1016/S0891-5849(99)00224-5)

Reno, F. \& Cannas, M. 2006 UHMWPE and vitamin E bioactivity: an emerging perspective. Biomaterials 27, 3039-3043. (doi:10.1016/j.biomaterials.2006.01.016)

Reno, F., Ainna, V., Gatti, S. \& Cannas, M. 2005 Effect of vitamin $\mathrm{E}$ addition to poly(DL-lactic acid) on surface properties and osteoblast behaviour. Biomaterials 26, 5594-5599. (doi:10.1016/j.biomaterials.2005.02.015)

Rezwan, K., Chen, Q. Z., Blaker, J. J. \& Boccaccini, A. R. 2006 Biodegradable and bioactive porous polymer/inorganic composite scaffolds for bone tissue engineering. Biomaterials 27, 3413-3431. (doi:10.1016/j.biomaterials. 2006.01.039)

Seal, B. L., Otero, T. C. \& Panitch, A. 2001 Polymeric biomaterials for tissue and organ regeneration. Mater. Sci. Eng. R. 34, 147-230. (doi:10.1016/S0927-796X(01)00035-3)

Valappil, S. P., Misra, S. K., Boccaccini, A. R. \& Roy, I. 2006 Biomedical applications of polyhydroxyalkanoates, an overview of animal testing and in vivo responses. Expert Rev. Med. Devices 3, 853-868. (doi:10.1586/17434440.3.6.853)

Valappil, S. P., Misra, S. K., Boccaccini, A. R., Keshvaraz, T., Bucke, C. \& Roy, I. 2007 Large scale production and efficient recovery of $\mathrm{PHB}$ with desirable material properties, from the newly characterised Bacillus cereus SPV. J. Biotechnol. 132, 251-258. (doi:10.1016/j.jbiotec.2007. 03.013)

Voegele, A. F., Jerkovic, L., Wellenzohn, B., Eller, P., Kronenberg, F., Liedl, K. R. \& Dieplinger, H. 2002 Characterisation of the vitamin E-binding properties of human plasma afamin. Biochemistry 41, 14 532-14 538. (doi:10.1021/bi026513v)

Webster, T. J., Siegel, R. W. \& Bizios, R. 1999 Osteoblast adhesion on nanophase ceramics. Biomaterials 20, 1221-1227. (doi:10.1016/S0142-9612(99)00020-4)

Xu, H., Watkins, B. A. \& Seifert, M. F. 1995 Vitamin E stimulates trabecular bone formation and alters epiphyseal cartilage morphometry. Calcif. Tissue Int. 57, 293-300. (doi:10.1007/BF00298885)

Yefang, Z., Hutmacher, D. W., Varawan, S.-L. \& Meng, L. T. 2007 Comparison of human alveolar osteoblasts cultured on polymer-ceramic composite scaffolds and tissue culture plates. Int. J. Oral Maxillofac. Surg. 36, 137-145. (doi:10. 1016/j.ijom.2006.08.012) 